\title{
ILCEA
}

Revue de l'Institut des langues et cultures

d'Europe, Amérique, Afrique, Asie et Australie

46 | 2022

Refuges identitaires numériques

\section{Online Identity and Egyptian Youth: Exploring}

\section{Construction Processes}

Identité en ligne et jeunesse égyptienne : exploration des processus de construction

\section{Hanan Ezzat}

\section{OpenEdition}

\section{Journals}

Electronic version

URL: https://journals.openedition.org/ilcea/13947

DOI: 10.4000/ilcea.13947

ISSN: 2101-0609

\section{Publisher}

UGA Éditions/Université Grenoble Alpes

\section{Printed version}

ISBN: 978-2-37747-331-1

ISSN: $1639-6073$

\section{Electronic reference}

Hanan Ezzat, "Online Identity and Egyptian Youth: Exploring Construction Processes ", ILCEA [Online], 46 | 2022, Online since 02 March 2022, connection on 04 March 2022. URL: http:// journals.openedition.org/ilcea/13947 ; DOI: https://doi.org/10.4000/ilcea.13947

This text was automatically generated on 4 March 2022.

(C) ILCEA 


\title{
Online Identity and Egyptian Youth: Exploring Construction Processes
}

\author{
Identité en ligne et jeunesse égyptienne : exploration des processus de \\ construction
}

Hanan Ezzat

\section{Introduction}

1 This study takes place in Egypt, a patriarchal, conservative and keenly religious country. Egypt, geographically situated in Africa, is part of the Middle East Region-also known as the Arab World-a group of countries bound by geography and language. The Arab World depended for a long time on rigid, oral, and tradition-based formats till the advent of social media (Ayish \& Alnajjar, 2019). There is great respect for a patriarchal structure and societal norms are highly regarded. The population in the Arab World is relatively young, with adolescents and youth aged 10 to 24 years representing one quarter of the total population (United Nations, 2019).

2 Egypt boasts a large youth bulge whereby $40 \%$ of the society is between the age of 10 and 29 years (Roushdy \& Sieverding, 2015). This high percentage renders importance to youth; they are considered catalysts given their role in the Arab Spring and the Egyptian revolution. Egyptian youth hold traditional Arabic values very close to them and this means that there is a respect for the elder, the family as a social unit is highly respected and there is a preference of men over women. At the same time Egyptian youth have an affinity towards global values such as unity, community, diversity, tolerance, empowerment, creativity, integrity and equality. They aspire to take on these global values although in many cases societal constraints prevent them from doing so. The society expects quite a lot from youth who face insurmountable socioeconomic challenges and are struggling with their identity just like youth around the world (Amin, 2000, 2013; Dhillon \& Yousef, 2009; Rashad, Osman \& Roudi-Fahimi, 2005). Typically, they undergo a "crisis" with their identity in which they address key questions about their values and ideals, their future occupation or career, and their 
sexual identity (Erikson, 1968). In the past, youth drew on traditional structures such as family and societal norms for guidance. This is now shifting with the advent of alternative sources of information such as social media and consequently social media influencers (hereafter influencers). Influencers are ordinary individuals who narrate their life and use social media platforms to build their fan bases. They use digital spaces effectively and monetize their existence (Abidin, 2015). In Egypt, in spite of being a new phenomenon, influencers have grown in numbers, covering all genres of content from narrating their lifestyle to reviewing products, providing self-development advice and presenting less serious content.

3 Social media have become intertwined with mass media in all societies across the globe and a part of the daily lives of millions. In the Arab World and in Egypt in particular, social media took center stage during the Arab Spring. This brought attention to the role social media played in mobilizing societies and for at least a decade this was the focus of most research coming out from or about this part of the world (Attia, Aziz, Friedman \& ElHusseiny, 2011; Herrera, 2012; Khamis, Gold \& Vaughn, 2012; Olorunnisola \& Martin, 2013). This dominating research focus marginalized the other roles social media, and its constituents play in society and overlooked the significant societal role of social media. Accordingly, this study fills a void in research contributing to studies on youth, online identity and influencers in this part of the world.

The majority of studies focusing on youth, online identity and influencers are set and conducted in Western (European and American) contexts primarily with a focus on youth (Bazarova, Taft, Choi \& Cosley, 2013; Mazur \& Kozarian, 2010). Although the characteristics of Western youth are similar to Egyptian youth in their struggle with identity, there are fundamental differences between them. For example, in most Western countries youth are expected to start to move out of their parents' home by the age of 18 and start to become more independent. However, youth in Egypt stay with their parents beyond the age of 18 and well into their twenties and thirties, in most cases, till they get married. This makes them fully dependent on their parents financially, psychologically and in many other ways (Amin, 2000). Another glaring difference is in postponing marriage in the West, which happens due to youth pursuing their careers or education (Davis \& Weinstein, 2017); however, in Egypt marriage is postponed due to financial constraints as the cost of marriage is quite high while at the same time relationships outside of marriage are frowned upon in the society. Accordingly, the results of studies conducted in the West are not necessarily applicable to Egyptian youth who have a different outlook and navigate a completely different landscape.

5 The focus of the study is Facebook mainly as it provides a range of processes to establish an online identity. When users create a new account it includes an account name, profile photograph, a small description about the user containing basic information. To use YouTube users simply need a Google account, while Instagram users can $\log$ in with their Facebook accounts. Livingstone elaborates "the very language of social relationships is being reframed; today, people construct their 'profile', make it 'public' or 'private', they 'comment' or 'message' their 'top friends' on their 'wall', they 'block' or 'add' people to their network, and so forth" (2008: 4).

6 To explore the topic of online identity construction processes of Egyptian youth, the study will address the following research questions: How do fans construct and present their online identity on Facebook? How do they see themselves as fans? And, does 
becoming a fan of an influencer play a role in online identity construction on Facebook?

\section{Theoretical Framework}

7 The search for the answer to: "Who-am-I?" has been a long quest for many scholars in various fields including psychologists, sociologists, philosophers and anthropologists (Johnston, 2012). This quest also exists in Egypt where questions about identity are asked and discussed by youth daily; they try to make sense of events around them by understanding more about their own identity and situating themselves in the world. Identity per se is one of the fastest growing areas in the social sciences (Côté, 2006).

With the advent of social media, there are new means to construct identity and new forms of identity hence online identity, with self-presentation at the heart of it. Selfpresentation is "a minimum" requirement for participation on Social Networking Services (SNS) by users and one of the most important pieces of SNSs (Tufekci, 2008). Consequently, research about self-presentation has exploded in the last 25 years (Schlenker, 2003). This demonstrates that online identity and self-presentation are timely topics for research.

9 This study draws upon the work of two key scholars who profoundly influenced studies about online identity and self-presentation. The first scholar is Goffman, who outlined in his book The Presentation of Self in Everyday Life the foundations of self-presentation (Goffman, 1959). Prior to the digital age he built his premise on a dramaturgical approach borrowing concepts from theatre whereby individuals set out to build an impression on others. He explains at great length how individuals build a specific impression and links it to the audience or "others" present (Goffman, 1959). Numerous studies conducted in the West have been guided by Goffman's work including studies focusing on social media (Birnbaum, 2008; Bullingham \& Vasconcelos, 2013; Burns, 1992; Nesvadba, 2017; Serpa \& Ferreira, 2018; Smith, 2006). Goffman's relevance is in that he provides a sound framework to the study to talk about online identity and selfpresentation processes and tactics. The second scholar, which this study will draw on, is Leary and his self-presentation tactics (Leary, 1996). Leary highlighted a number of tactics individuals depend on for self-presentation such as self-descriptions, attitude statements, public attributions, remembering and forgetting, nonverbal behavior, social associations, conformity and compliance, the physical environment and other tactics. The study focuses on the key tactics which can be observed in the presentation of online identity. Goffman's approach and Leary's tactics may offer insights on the way fans present themselves online. They may also help make sense of how Egyptian youth construct their online identity and how becoming a fan of an influencer plays a role in the way youth present themselves online.

Additionally, this study draws upon the theoretical concepts of identification and parasocial relationships, to provide other interpretations to the findings of the research questions. Identification pertains to when individuals adopt behaviours from others because they have a satisfying self-defining relationship with a group (Kelman, 1961). Identification with media characters has generally been understood to denote feelings of affinity, friendship, similarity, and liking of media characters or imitation of a character by audience members (Liebes \& Katz, 1990). As for parasocial relationships, they are one-sided imaginary relationships with media personae which individuals 
experience as real relationships (Horton \& Wohl, 1956; Rubin \& McHugh, 1987). It's worth noting that parasocial relationships are a normal part of social development during adolescence and early youth as confirmed by studies (Adams-Price \& Greene, 1990; Greene \& Adams-Price, 1990; Steele \& Brown, 1995).

\section{Methodology}

11 To answer the research questions and given the exploratory nature of this study, it was deemed that a qualitative approach will be best suited. Qualitative research is characteristically exploratory, fluid and flexible, data-driven and context-sensitive (Mason, 2002). Therefore, given the Egyptian context, which is skeptical in nature towards research, it was important to depend on a qualitative methodology. Furthermore, Bullingham and Vasconcelos (2013) argue that online identity has a complex nature which renders special attention. This nature dictates investigation of rich data such as opinions and observations of users and what they think. Rich data is key to this study where online identity and its construction is explored. Accordingly, the study sought the views of fans, on how they construct their online identity and how being a fan plays out in that.

12 This study depended on semi-structured in-depth interviews with 18 fans of influencers. To select the participants, purposive non-probability sampling was used with a set of inclusion criteria (Given, 2008). The criteria included fans being Egyptian, in the age bracket of 18-24 years of age, diverse in gender and represented socioeconomic levels.

13 Fans were recruited and contacted through Facebook's messaging application "Messenger". Target participants were clear about their preferred method and place of interview and the interviews were conducted accordingly. During the interviews, the profiles of the fans were viewed with their consent. Fans took the researcher through how they construct their profile and what type of content is on it.

14 A total of 26 interviews were conducted in the period 10 March to 20 April 2019 out of which 18 were successful. The successful fans interviewed were: 11 female and 7 males; and 12 from Cairo and 6 from other Governorates (mix of urban and rural Governorates). Ten of the interviews were conducted by phone/text/voice notes and 8 face-to-face. For the sake of anonymity, all fans were assigned alias names to safeguard their real identities.

15 An inductive approach of analysis was used to analyse the interviews (Blair, 2015). The starting point was open coding, which provided a clean slate, then axial coding to interconnect the categories and then selective coding to pick on certain codes to develop the results. The analysis of the interviews with the fans revealed a number of important themes from a fan point of view which are the foundation for the key findings. The themes that were developed from the analysis of the interviews included the following: 1) Online identity and self-presentation 2) Perceptions 3) Fandom Experience. The subcategories included: co-construction, photographs, sharing, being a fan, use of influencer photographs, identification; and changes in attitudes and behaviours. 


\section{Findings and Discussion}

16 Fans spoke about how they set out to give a certain impression to others. In that they were in line with Goffman's dramaturgical approach. To achieve this, they "performed", they strived to be visible to others online. According to Hill nowadays if you are not on Facebook, it's likely that you don't exist (Hill, 2012). Davies asserts this stating: "Simply belonging to Facebook is a statement of identity" (Davies, 2012: 27). In the following the findings will be discussed more closely in relation to the research questions.

On the first question of how fans constructed and presented their online identity on Facebook, the analysis of the interviews revealed that fans aimed to create an online self-narrative which is continuously evolving as long as they are online. The elements of this online self-narrative they spoke about included co-construction of their online identity; the use of photographs; and sharing content with others. The findings showed discrepancies between men and women. Throughout the interviews, fans spoke of ownership of their profiles, they described them as an extension of their offline identity with no talk of pretending to be someone else or presenting a different identity. On the contrary, most spoke about presenting an authentic and honest portrayal of themselves.

Fans spoke about how they co-constructed their online identity. Co-construction meant that they took others into consideration when creating or sharing content on their own profiles (pages). Mona, female, 21, stated: "Definitely, I think of people's reactions especially that I have my whole family on my page. So, they see what I do". Coconstruction is backed up by a number of studies (Boyd, 2008; Livingstone \& Brake, 2010; Merchant, 2005). Fans listed a number of groups which they take into consideration. The first and most important group was "parents" which reflects the patriarchal nature of the Egyptian society. Amr, male, 19, said: "My parents are on my account, so I don't want problems". Family remains an important social construct. Other groups included friends and even potential employers; influencers were not highlighted as one of the groups. David, male, 21, said: "I can't share because there are employers and my parents, so I have to carry a certain image".

An important identity marker and part of a Facebook profile is photographs (Greenhow \& Robelia, 2009; Mallan \& Giardina, 2009). Facebook employs a number of photographs such as the profile photograph, the cover photographs and photographs which can be uploaded, tagged, shared and organized as albums. Different account settings provide accessibility options to photographs. There were wide disparities between males and females in terms of the selection of photographs. Most male fans used their own photograph as profile photographs, while some female fans opted for other photographs such as those of animals, plants, objects and abstract photographs. In some cases, female fans opted for not using photographs at all, in which case the photograph appears as a shadowed one. These photographs don't ascertain the identity of their owner. To be able to ascertain the identity a name is needed with the photograph and even with a name the identity can still remain unclear. Representing identity using these photographs contradicts the notion of 'Who-I-am' developed by Wynn and Katz (1997), in which identity tends to be expressed in a photograph.

There were a number of reasons stated by female fans as to why they opted for not using a photograph or using non-personal photographs. These included religious 
reasons, for example Eman, female, 21, stated: “I haven't put my photograph because I don't like to because of religious reasons, I was told that when I put my photograph and boys could see it then I have done something wrong religiously". Others spoke about societal constraints related to gender, for example Hanya, female, 20, said:

First of all, how can a girl publish her photograph on Facebook in public in this society in which people concentrate and focus on everything? So, I didn't want to publish my photograph on Facebook. My photograph belongs to me and I can share it with my friends on WhatsApp. I didn't find any benefit in publishing it on Facebook.

The reasons stated all reflect the religiously keen and conservative nature of the Egyptian society (Mensch, Ibrahim, Lee \& El-Gibaly, 2003; Roushdy \& Sieverding, 2015). The reasons also indicate that fans apply Leary's compliance and conformity tactic (Leary, 1996) in which they comply and conform with Egyptian societal norms. This finding contradicts Western studies, in which both males and females actively use their photographs on social media, differences are related to the type of photograph not its existence and there are gendered display identities (Bond, 2009; Crescenzi, Araüna \& Tortajada, 2013; Hum et al., 2011; Siibak, 2009; Strano, 2008; Tortajada-Giménez, Araüna-Baró \& Martínez-Martínez, 2013; Young \& Quan-Haase, 2009).

When probed specifically about using the influencer's photograph as their own profile photograph fans did not entertain the idea regardless of their degree of admiration of the influencer. Osama, male, 24, said: "I feel that this is a sick idea to use someone else's photograph, people have their reasons to do it, but I don't think it's right". Dina, female, 24, stated: "When you use someone else's photograph on your account people can get mixed up and don't know who you are".

To construct their online identity, youth fans shared content of others (pages and groups) on their pages. In that they were implicitly approving the content and that content in turn, would help shape the impressions others took of them. Some fans shared content produced by influencers and in that they were creating social associations with the influencers (Leary, 1996). Heba, female, 21, said: "In the last period I shared any video they uploaded". Mo, male, 19, echoed this: "I do share some of their content, especially strong content and things that touch me and can touch others when I share it". Some fans shared videos and content by influencers to reach others and spread that content. Sahar, female, 21, stated: "Yes, all the time. I share videos which I like". Dalia, female, 18, elaborated: "I share his (the influencer) content to support him and also if I like what he presents I share it to reach more people". In sharing the content of influencers fans publicise that they are a fan, and they endorse the influencers content, messages and ideas through sharing them on their own profiles. The impression others could take of them could be based on that content or those ideas, so they become part of their online identity.

Some female fans hid behind male identities of their brother/father/fiancé/husbands' accounts and masked their identity. The account name that appears is not a pseudonym but a male name, so they were using a male identity but acting as females online, for example, asking questions related to menstruation on a personal hygiene video by influencers. Experimentation here took the form of experimenting with an identity which is not one's own. There are plausible explanations for why females mask their real identity behind a male one. The first explanation is that when females mask their identity, they can navigate different spaces online without anyone knowing their real identity, this gives them freedom and liberty to do and say what they want. They can 
experiment with their identity without being known to others and in that they can take risks and do anything online, which is a typical characteristic of youth who experiment with their identity (Turkle, 1995). The second plausible explanation is that hiding behind a male identity conforms very much with this patriarchal society and means that they can benefit from preference of males in the society and as a result of that, they can get likes, comments and answers to their questions (Mensch, Ibrahim, Lee \& El-Gibaly, 2003; Roushdy \& Sieverding, 2015). This finding is very unique to the Arab World and Egypt.

On the second research question on how fans see themselves as fans; they invest their time in following influencers and actively engaging with them (Jenkins, 1992; Schimmel, Harrington \& Bielby, 2007). Fans were able to describe themselves as fans accurately drawing on their online and offline behaviours towards the influencer. They mentioned they could carry out one or more of these behaviours. For online behaviours, the first set of behaviours was to follow the influencer on all social media platforms. Amal, female, 20, said: "A fan means somebody who follows someone he loves and also he loves the content presented". Also, to continuously refresh the influencers page to check if everything new has been uploaded. Motaz, male, 24, said: "I go in and check regularly if they have uploaded a new video". Combined with this behaviour was waiting in anticipation for new videos. Eman, female, 21, said:

I really wait for her videos; I have notifications turned on for her channel so any

videos she puts I see as soon as they are uploaded. I wait for her videos and also

stories on Facebook and Instagram, for me she is number 1.

The second set of behaviours was to watch everything the influencer uploaded, stories and read all their posts. Sahar, female, 21, said: "I am a fan; I watch all of his videos". Combined with this was watching the video as soon as it was uploaded. Adam, male, 21, said: "This means as soon as he uploads a video, I see it within three minutes of uploading. I will watch it immediately". The third set of behaviours was liking the video, post or story and according to Facebook, people who click the Like button are more engaged than average Facebook users (Facebook, 2010). Combined with this was sending emojis or emoticons to influencers on their stories. The fourth set of behaviours was commenting on videos, posts or stories. Combined with this was sharing the influencers' content on users home pages. The fifth set of behaviours was loyalty to the influencer Osama, male, 24, explained: "For me fan it means that I defend that person all the time and that I am loyal to them". Combined with this was loving the influencer regardless of the content they presented.

On the third question of if becoming a fan of an influencer plays a role in online identity construction; fans spoke about feeling some sort of affinity towards influencers, an affinity representing part of identification. Talking about an influencer she followed, Sahar, female, 21, said: "I feel that he is an Egyptian guy who goes through similar things as other youth his age and he deals with these issues in a comic manner. I feel he is like me and my brothers". Perihan, female, 23, echoed this, talking about her favorite influencer: "She is similar to me. She can talk and has a nice sense of humour. I like the way she dresses and her makeup". Other fans used words which indicated the development of a parasocial relationship with influencers; these words were in line with Caughey's (1984) description of how fans behave. He explains that they refer to their hero as a friend or an older sister or mentor or father figure or guide. Furthermore, fans spoke of how influencers helped them change their attitudes and behaviours. Specific examples of changes that were mentioned included the 
following. Motaz, male, 24, stated: "He influences my life". Eman, female, 21, said: "The other thing I took from her is that you should develop yourself all the time". Dina, female, 24, said:

Yes, my thinking. Every year these people add something to my thinking, for example that something new should be included in my priority list. They add something to me. They talk about problems you face in real life. There are a lot of things I learnt from them.

In this case, and through identifying with influencers, fans were influenced and took on the ideas, thoughts and behaviours of influencers, which consequently helped them change their attitudes, thoughts and behaviours.

\section{Conclusions}

The findings can be summarized in that when youth become fans of influencers this ultimately reflected on how they constructed their online identity especially on the side of content they shared or adoption of their ideas and values in their own posts. However, becoming a fan did not necessarily reflect directly on the fans' profile such as using the photograph of the influencer as their own profile photograph. There were discrepancies between males and females in identity construction especially in revealing their identity and use of photographs.

It was evident through the study that online identity construction is an ongoing process, it does not end with selecting a profile photograph or sharing some content as individuals continuously change how they appear online and also what they share and communicate. Identity is routinely created and sustained in the reflexive activities of the individual (Giddens, 1991). As youth undergo different experiences or get exposed to different sources of information-one of which is social media and influencers-they reflect on these experiences, reassess their thinking and attitudes and consequently their behaviours. All of these reflexive moments will impact how they create their online narrative. In reality fans' profiles are like moving targets, they change all the time.

1 The results of this study should be considered through its context which is Egypt. Egyptian youth interact daily in a traditional, patriarchal, religiously keen society. This impacts on everything as well as how they use their time and consume social media. Egyptian youth also face a delay in major milestones such as marriage and employment, which influences their identity development and makes it skewed more towards that of adolescents than young emerging adults (Davis \& Weinstein, 2017).

One limitation related to this study is the sample of 18 Egyptian youth fans. The sample size is adequate for the exploratory study as this one. However, the results cannot be generalized to the entire population of Egyptian youth. Another limitation is the linguistic aspect. This study was conducted in Egypt interviewing Egyptian participants in Arabic. The Arabic interview transcripts were then translated into English. In spite of every attempt taken not to literally translate but to project an accurate meaning of every word said, the reader may miss some local nuances.

This study contributes to the body of studies about youth, influencers and online identity. It links youth processes of identity construction to influencers. It highlights how youth fans perform in a non-Western culture. The findings can be used by key stakeholders with an interest in youth, to enable them to reach them more effectively 
through the influencers. Influencers can be used to propagate specific messages and create awareness around pressing societal issues.

For future studies, one recommendation is to take a larger sample from across Egyptian youth so that the results are more representative. Another recommendation is to include other groups such as parents of the youth fans. Additional ethnographic tools can be used such as observation in universities or clubs (if appropriate permissions are obtained). In future studies, and to reflect the ever-changing social media scene, other social media personae and platforms can be explored and the link with online identity can be established. For example, a study could look at the world-renowned Egyptian footballer Mo Salah and the online identity of Egyptian youth. Tik Tok has the potential to be a subject of a study as it is gaining momentum in Egypt.

\section{BIBLIOGRAPHY}

ABIDIN Crystal (2015), "Communicative intimacies: Influencers and Perceived

Interconnectedness”, Ada: A Journal of Gender, New Media, and Technology, 8, <https://doi.org/ 10.7264/N3MW2FFG>.

ADAMS-PRICE Carolyn \& GREENE A. L. (1990), “Secondary attachments and adolescent self-concept”, Sex Roles, 22(3-4), 187-198, <https://doi.org/10.1007/BF00288191>.

Amin Galal (2000), Whatever happened to the Egyptians? Changes in Egyptian Society from 1950 to the present, Cairo, Egypt: The American University in Cairo Press.

AmIN Galal (2013), Whatever Happened to the Egyptian Revolution, Cairo, Egypt: The American University in Cairo Press.

AtTia Ashraf, Aziz Nerges, Friedman Barry \& ElHusseiny Mahdy (2011), “Commentary: The impact of social networking tools on political change in Egypt's 'Revolution 2.0", Electronic Commerce Research and Applications, 10(4), 369-374, <https://doi.org/10.1016/j.elerap.2011.05.003>.

AYISH Mohammad \& ALNAJJAR Abeer (2019), “Arab millennial identity in cyberspace Arab Millennials' Articulation of Identity in Cyberspace: A study of three MENA YouTubers", Arab Media and Society, Winter/Spring (27), 26-40.

BAZARova Natalya, TAFT Jessie, CHOI Yoon Hyung \& Cosley Dan (2013), “Managing Impressions and Relationships on Facebook", Journal of Language and Social Psychology, 32(2), 121-141, <https:// doi.org/10.1177/0261927X12456384>.

BIRNBAUM Matthew (2008), Taking Goffman on a tour of Facebook: College students and the presentation of self in a mediated environment (doctoral thesis), University of Arizona, Tucson, <https:// repository.arizona.edu/handle/10150/194670> (January 9, 2021).

BLAIR Erik (2015), “A reflexive exploration of two qualitative data coding techniques”, Journal of Methods and Measurement in the Social Sciences, 6(1), 14-29, <https://doi.org/10.2458/v6i1.18772>.

Bond Bradley (2009), “He Posted, She Posted: Gender Differences in Self-disclosure on Social Network Sites", Rocky Mountain Communication Review, 6(2), 29-37. 
Boyd Danah (2008), Taken Out of Context: American Teen Sociality in Networked Publics (doctoral thesis), University of California, Berkeley, <https://www.ischool.berkeley.edu/research/ publications/2008/taken-out-context-american-teen-sociality-networked-publics> (January 12, 2021).

Bullingham Liam \& VAsConCElos Ana (2013), “The presentation of self in the online world: Goffman and the study of online identities", Journal of Information Science, 39(1), 101-112, <https:// doi.org/10.1177/0165551512470051>.

BURNS Tom (1992), Erving Goffman, London, UK: Routledge.

CAUGHEY John (1984), Imaginary social worlds: a cultural approach, Nebraska, USA: University of Nebraska Press.

CôTÉ James (2006), “Identity Studies: How Close Are We to Developing a Social Science of Identity? -An Appraisal of the Field", Identity, 6(1), 3-25, <https://doi.org/10.1207/s1532706xid0601_2>.

CRESCEnZI Lucrezia, ARAüNA Nuria \& TORTAJADA Iolanda (2013), "Privacy, self-disclosure and selfimage of Spanish teenagers on social networking sites. The case of Fotolog",

Communication \& Society/Comunicación y Sociedad, 26(2), 65-78.

DAVIES Julia (2012), "Facework on Facebook as a new literacy practice", Computers \& Education, 59(1), 19-29, <https://doi.org/10.1016/j.compedu.2011.11.007>.

Davis Katie \& Weinstein Emily (2017), “Identity Development in the Digital Age”, M. Wright (ed.), Identity, Sexuality, and Relationships among Emerging Adults in the Digital Age, Hershey: IGI Global, 117.

DHILLON Navtej \& YouSEF Tarek [eds] (2009), Generation in Waiting: The Unfulfilled Promise of Young People in the Middle East, Washington DC, USA: Brookings Institute Press.

ERIKSON Erik (1968), Identity: Youth and Crisis, New York, USA: W.W. Norton \& Company.

FАСЕВоОК (2010), The value of a liker, online at <https://www.facebook.com/notes/facebookmedia/the-value-of-a-liker/150630338305797/> (1 February 2021).

GIDDENS Anthony (1991), Modernity and Self-Identity Self and Society in the Late Modern Age, California, USA: Stanford University Press.

GIVEN Lisa [ed.] (2008), The SAGE Encyclopaedia of Qualitative Research Methods Volumes 1\&2, New York, USA: SAGE Publications.

GoFfMAN Erving (1959), The Presentation of Self in Everyday Life, New York, USA: Doubleday.

GREENE A. L. \& ADAMS-PRICE Carolyn (1990), “Adolescents' secondary attachments to celebrity figures”, Sex Roles, 23(7-8), 335-347, <https://doi.org/10.1007/BF00289224>.

GREENHOW Christine \& ROBELIA Beth (2009), "Informal learning and identity formation in online social networks", Learning, Media and Technology, 34(2), 119-140, <https://doi.org/ 10.1080/17439880902923580>.

HERRERA Linda (2012), "Youth and Citizenship in the Digital Age: A View from Egypt", Harvard Educational Review, 82(3), 333-352, <https://doi.org/10.17763/haer.82.3.88267r117u710300>.

Hill Kashmir (2012), “Beware, Tech Abandoners. People Without Facebook Accounts Are 'Suspicious", online at Forbes: <https://www.forbes.com/sites/kashmirhill/2012/08/06/bewaretech-abandoners-people-without-facebook-accounts-are-suspicious/\#6e510c128f95>. 
HORTON Donald \& WoHL Richard (1956), “Mass Communication and Para-Social Interaction", Psychiatry, 19(3), 215-229, <https://doi.org/10.1080/00332747.1956.11023049>.

Hum Noelle, Chamberlin Perrin, Hambright Brittany, Portwood Anne, Schat Amanda \& BeVAN Jennifer (2011), "A picture is worth a thousand words: A content analysis of Facebook profile photographs", Computers in Human Behaviour, 27(5), 1828-1833, <https://doi.org/10.1016/j.chb. 2011.04.003>.

JENKINS Henry (1992), Textual Poachers: Television Fans and the Participatory Culture, London, UK: Routledge.

JoHNSTON Jenny (2012), “Using identity as a tool for Investigation: a methodological Option in the researcher's toolbox", International Journal of Arts \& Sciences, 5(5), 1-9.

Kelman Herbert (1961), “Processes of opinion change”, Public Opinion Quarterly, 25(1), 57-78.

KHAMIS Sahar, Gold Paul \& VAUGHN Katherine (2012), “Beyond Egypt's 'Facebook Revolution' and Syria's 'YouTube Uprising': Comparing Political Contexts, Actors and Communication Strategies", Arab Media \& Society, 15(Spring), 1-30, <https://www.arabmediasociety.com/beyond-egyptsfacebook-revolution-and-syrias-youtube-uprising-comparing-political-contexts-actors-andcommunication-strategies/>.

LEARY Mark (1996), Self-presentation: Impression management and interpersonal behaviour, London, UK: Routledge.

LIEBES Tamar \& KATZ Elihu (1990), The export of meaning: Cross-cultural readings of Dallas, Oxford, UK: Oxford University Press.

LIVINGSTONE Sonia (2008), “Taking risky opportunities in youthful content creation: teenagers' use of social networking sites for intimacy, privacy and self-expression", New Media \& Society, 10(3), 393-411, <https://doi.org/10.1177/1461444808089415>.

LIVINGSTONE Sonia \& BRAKE David (2010), “On the Rapid Rise of Social Networking Sites: New Findings and Policy Implications”, Children \& Society, 24(1), 75-83, <https://doi.org/10.1111/j. 1099-0860.2009.00243.X>.

MALLAN Kerry \& GIARDINA Natasha (2009), “Wikidentities: Young people collaborating on virtual identities in social network sites”, First Monday, 14(6), <https://doi.org/10.5210/fm.v14i6.2445>

MASON Jennifer (2002), Qualitative Researching (2nd ed.), New York, USA: SAGE Publications Ltd.

MAZUR Elizabeth \& KOZARIAN Lauri (2010), "Self-Presentation and Interaction in Blogs of Adolescents and Young Emerging Adults", Journal of Adolescent Research, 25(1), 124-144, <https:// doi.org/10.1177/0743558409350498>.

MensCh Barbara, IBRAhim Barbara, LeE Susan \& El-Gibaly Omnia (2003), “Gender-role Attitudes among Egyptian Adolescents”, Studies in Family Planning, 34(1), 8-18, <https://doi.org/10.1111/j. 1728-4465.2003.00008.X>.

MERCHANT Guy (2005), “Electric Involvement: Identity performance in children's informal digital writing", Discourse: Studies in the Cultural Politics of Education, 26(3), 301-314, <https://doi.org/ 10.1080/01596300500199940>.

NESVADBA Noe (2017), The presentation of self in the digital world: Goffman and the study of Women's selfportrayal on Instagram through selfies (master's thesis), Loughborough University, Loughborough, <https://www.academia.edu/36582334/ 
The_Presentation_of_Self_in_the_Digital_World_Goffman_and_the_Study_of_Womens_Self_Portrayal_on_Instagram_through_Selfies (February 20, 2021).

OlORUNNISOLA Anthony \& MARTIN Brandie (2013), "Influences of media on social movements: Problematizing hyperbolic inferences about impacts”, Telematics and Informatics, 30(3), 275-288, $<$ https:doi.org/10.1016/j.tele.2012.02.005>.

RASHAD Hoda, OSMAN Magued \& RoUDI-FAHIMI Farzaneh (2005), Marriage in the Arab World, Washington DC: Population Reference Bureau.

RoBINSON Oliver (2014), "Sampling in Interview-Based Qualitative Research: A Theoretical and Practical Guide”, Qualitative Research in Psychology, 11(1), 25-41, <https://doi.org/ 10.1080/14780887.2013.801543>.

ROUSHDY Rania \& SIEVERDING Maia [Eds] (2015), Panel survey of young people in Egypt 2014: Generating evidence for policy, programs, and research, Cairo: Population Council.

RUBIN Rebecca \& McHuGH Michael (1987), “Development of parasocial interaction relationships”, Journal of Broadcasting \& Electronic Media, 31(3), 279-292, <https://doi.org/

10.1080/08838158709386664>.

SCHIMMEL Kimberly, HARRINGTON Lee \& BIELBY Denise (2007), "Keep Your Fans to Yourself: The Disjuncture between Sport Studies' and Pop Culture Studies' Perspectives on Fandom”, Sport in Society, 10(4), 580-600, <https://doi.org/10.1080/17430430701388764>.

SCHLENKER Barry (2003), “Self-presentation”, M. Leary \& J. Tangney (eds), Handbook of Self and Identity, New York: The Guilford Press, 492-518.

SERPA Sandro \& FerReIRA Carlos Miguel (2018), “Goffman's Backstage Revisited: Conceptual Relevance in Contemporary Social Interactions", International Journal of Social Science Studies, 6(10), 74, <https://doi.org/10.11114/ijsss.v6i10.3659>.

SIIBAK Andra (2009), "Constructing the Self through the Photo selection - Visual Impression Management on Social Networking Websites", Cyberpsychology, 3(1), 1-9, <https://

cyberpsychology.eu/article/view/4218/3260>.

SMITH Greg (2006), Erving Goffman, London, UK: Routledge.

STEELE Jeanne \& BROWN Jane (1995), “Adolescent room culture: Studying media in the context of everyday life", Journal of Youth and Adolescence, 24(5), 551-576, <https://doi.org/10.1007/ BF01537056>.

STRANO Michele (2008), "User Descriptions and Interpretations of Self-Presentation through Facebook Profile Images", Cyberpsychology: Journal of Psychosocial Research on Cyberspace, 2(2), <https://cyberpsychology.eu/article/view/4212/3253>.

TORTAJADA-GIMÉNEZ Iolanda, ARAÜNA-BARÓ Nuria \& MARTÍNEZ-MARTÍNEZ Inmaculada-Jose (2013), "Advertising Stereotypes and Gender Representation in Social Networking Sites", Comunicar, 21(41), 177-186, <https://doi.org/10.3916/C41-2013-17>.

TUғEкCI Zeynep (2008), “Can You See Me Now? Audience and Disclosure Regulation in Online Social Network Sites”, Bulletin of Science, Technology \& Society, 28(1), 20-36, <https://doi.org/ 10.1177/0270467607311484>.

TURKLE Sherry (1995), Life on the Screen: Identity in the Age of the Internet, New York, USA: Simon \& Schuster Paperbacks. 
United NATIONS (2019), Population Division of the Department of Economic and Social Affairs of the United Nations Secretariat, World Population Prospects, online at <https://population.un.org/wpp/ Download/Standard/Population/> (11 January 2021).

WYNN Eleanor \& KATZ James (1997), "Hyperbole over Cyberspace: Self-Presentation and Social Boundaries in Internet Home Pages and Discourse", The Information Society, 13(4), 297-327, <https://doi.org/10.1080/019722497129043>.

YoUnG Alyson \& QUAN-HAASE Anabel (2009), "Information revelation and internet privacy concerns on social network sites", Proceedings of the Fourth International Conference on Communities and Technologies - C\&T '09, University Park, Pennsylvania, <https://doi.org/ 10.1145/1556460.1556499>.

\section{ABSTRACTS}

This qualitative study, conducted against the backdrop of Egypt, maps the different processes Egyptian youth use to construct their online identity. The Egyptian society is patriarchal, keenly religious and conservative and youth represent 40 per cent of the population. They are a very important group in society as there are many expectations of them as catalysts of change given their previous role in the Arab Spring. Youth employ a number of processes to construct their online identity including co-construction, selection and use of photographs and sharing content. Building on Goffman's dramaturgical approach and Leary's self-presentation tactics, the study looks closer at the online identity construction processes of eighteen Egyptian youth fans of social media influencers and how being a fan manifests itself in online identity presentation. The research questions are addressed through semi-structured interviews. The analysis revealed the various processes fans undertook, highlighted gender differences within some of the construction processes and identified processes which are unique to this part of the world.

Dans un contexte égyptien, une étude qualitative a été menée afin de cerner et explorer les différents processus adoptés par les jeunes égyptiens pour construire leur identité en ligne. La société égyptienne est patriarcale, profondément religieuse et conservatrice. Les jeunes représentent $40 \%$ de sa population et y jouent un rôle crucial, d'où leurs nombreuses attentes. $\mathrm{Vu}$ le rôle qu'ils ont joué auparavant notamment lors du « Printemps Arabe », ils sont considérés comme des catalyseurs de changement. Afin de construire leur identité en ligne, ils utilisent un certain nombre de processus, y compris l'auto-construction, la sélection et l'utilisation de photographies, et le partage de contenu. S'appuyant sur l'approche dramaturgique de Goffman et les tactiques d'auto-présentation de Leary, cette étude examine de plus près, d'un côté les processus de construction d'identité en ligne chez dix-huit jeunes amateurs de certains influenceurs des réseaux sociaux et, de l'autre, la manière dont se manifeste le fait d'être amateur dans la présentation des identités en ligne. Les questions de cette recherche ont été élaborées à travers des entretiens semi-structurés. L'analyse a révélé les différents processus que les amateurs adoptent, mis en évidence les différences liées au genre parmi certains processus de construction et identifié les processus spécifiques à cette partie du monde.

\section{INDEX}

Mots-clés: identité, jeunesse, réseaux virtuels, méthodes qualitatives, réseaux sociaux, Egypte Keywords: identity, youth, virtual networks, qualitative methods, social media, Egypt 
AUTHOR

HANAN EZZAT

Universitat Rovira i Virgili

hananezzat.ahmed@alumni.urv.cat 